Doell, R. G., and Kretchmer, N. (1962). Biochim. biophys. Acta (Amst.), 62, 353 .

Dunphy, J. V., Littman, A., Hammond, J. B., Forstner, G., Dahlqvist, A., and Crane, R. K. (1965). Gastroenterology, 49, 12.

Fischer, J. E. (1957). Amer. F. P Pysiol., 188, 49

Haemmerli, U. P., Kistler, H., Ammann, R., Marthaler, T., Semenza, G., Auricchio, S., and Prader, A. (1965). Amer. 7. Med., 38, 7.

Heilskov, N. S. C. (1951). Acta physiol. scand., 24, 84.

Herzenberg, L. A., and Herzenberg, L. A. (1959). Nutr. Rev., 17, 65.

Herzenberg, L. A., and Herzenberg, L. A. (1959). Nutr. Rev,

Holdsworth, C. D., and Dawson, A. M. (1965). Gut, 6, 387. $1,1126$.

Jeejeebhoy, K. N., Desai, H. G., and Verghese, R. V. (1964). Ibid., 2, 666.

Launiala, K., Kuitunen, P., and Visakorpi, J. K. (1966). Acta paediat. (Uppsala), 55, 257.

McMichael, H. B., Webb, J., and Dawson, A. M. (1965). Lancet, 1, 717.

Tars (1966). Brit. med. 7., 2, 1037.

Newcomer, A D. Clin. chim. Acta, 4, 395. Gastroenterology, 50, 340

Peternel, W. W. (1965). Ibid., 48, 299.
Plimmer, R. H. A. (1906). 7. Physiol. (Lond.), 35, 20.

Plotkin, G. R., and Isselbacher, K. J. (1964). New Engl. F. Med., 271, 1033.

Rosensweig, N. S., and Bayless, T. M. (1966). f. clin. Invest., 45, 1064. Rubino, A., Zimbalatti, F., and Auricchio, S. (1964). Biochim. biophys. Acta (Amst.), 92, 305.

Rutishauser, I. H. E. (1965). Lancet, 2, 565.

Sheehy, T W. and Anderson, P. R. (1965). Ibid., 2, 1.

Smith, C. A. (1959). The Physiology of the Newborn Infant, 3rd ed., p. 232, 235. Oxford.

Stanfield, J. P., Hutt, M. S. R., and Tunnicliffe, R. (1965). Lancet, 2, 519.

Sterk, V V., and Kretchmer, N (1964). Pediatrics, 34, 609.

Sunshine, P., and Kretchmer, N. (1964). Ibid., 34, 38.

Trowell, H."C. (1960). Non-infective Disease in Africa, pp. 331, 350. London.

Weijers, H. A., Van De Kamer, J. H., Dicke, W. K., and Ijsseling, J. (1961). Acta paediat. (Uppsala), 50, 55 .

Whitehead, R. G. (1964). Lancet, 1, 250.

- (1965). Ibid., 2, 567.

Wittmann, W., and Hansen, J. D. L. (1965). S. Afr. med. F., 39, 223.

\title{
Field Studies of Human Stress in Polar Regions
}

\author{
H. W. SIMPSON,* M.D., PH.D.
}

Brit. med. F., 1967, 1, 530-533

Why do explorers explore? The polar epics are a series of desperate situations-crevasses, starvation, cold, crushed ships, and so on. Do these "stress" the participants or are they comparatively unaffected because of a different constitution ? The term "stress" is used here to indicate any situation adverse to man associated with adrenocortical hyperactivity.

This study is an objective assessment of possible stress situations in Antarctic and Arctic regions; two indices of adrenocortical function-(1) the venous blood eosinophil count and (2) the urinary output of 17-hydroxycorticosteroids (17-OHCS) -were used.

The field work was carried out while I was a medical officer with the British Antarctic Survey and during a small expedition which skied 400 miles $(640 \mathrm{~km}$.) across the Greenland ice-cap.

\section{Methods}

Venous blood eosinophils were counted at once by the direct method of Thorn, Forsham, Prunty, and Hills (1948). Retrospective analysis of eosinophil scatter in the chambers showed almost perfect Poisson distribution (see Berkson, Magath, and Hurn, 1940). This indicates a satisfactory technique in spite of working in the field. For more details see Simpson (1959).

Total 17-OHCS were measured by a modification of Norymberski's technique (Appleby, Gibson, Norymberski, and Stubbs, 1955). Complete urine collections were made each day in polyethylene containers, the volume was recorded, and an 8-ml. aliquot taken. These small specimens, unpreserved, were then brought back to Glasgow for analysis. The storage qualities of these corticosteroid metabolites have already been investigated and found excellent (Simpson, 1965a, 1965b).

\section{Short-term Stress (One to Two Days)}

One man was studied over a period of two months at the base hut by making counts on alternate days. The object of this was to have a continuous tracing of eosinophil counts over a fairly long period and thus obtain a complete record of any

\footnotetext{
* University Department of Pathology, Royal Infirmary, Glasgow.
}

sudden unexpected events, which are always a possibility in Antarctica. The results are seen in Table I.

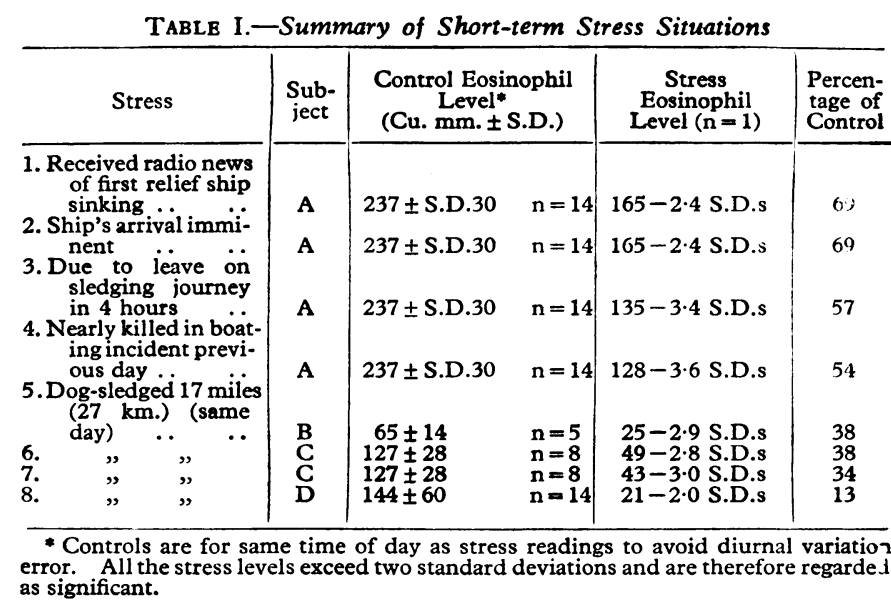

In stress 1 the relief ship was holed after hitting an ice floe and had to send out an S O S when the front hold filled with water. Boats were lowered. Later the master found that by going astern the leak was less serious and the pumps were gaining. All the base's mail, etc., was on board. This was the first ship for eight months.

In stress 4 an Argentine N.C.O. from an adjacent foreign base was being swept out to sea in a rowing-boat by the prevailing current. His outboard motor had run out of petrol and he lost the oars in the ensuing panic. Already one man had been killed in an identical manner the previous year, and as the weather was deteriorating the situation was desperate. This subject (A), with three companions, had put out to sea in a disused and leaky British rowing-boat in an attempt to reach the man, but after struggling for four hours they had to give up the attempt and only just managed to return, as by then a wind of gale force was blowing off shore. Fortunately the man was rescued later when a helicopter from an icebreaker spotted him 25 miles $(40 \mathrm{~km}$.) out.

Other opportunities for studying stress at the main base came with the arrival of dog-sledge parties returning from field work. 
The readings were made immediately and compared with controls taken at the same time of day. The results are given in Table I.

Since in all instances the eosinopenias are two standard durations below the control levels they are regarded as significant.

\section{Long-term Stress (Lasting Weeks or Months)}

\section{Prolonged Dog-sledging Journey}

This study was made during an 83-day period in the field in which four of us made a route on to the $7,000-\mathrm{ft}$. $(2,130-\mathrm{m}$.) ice-capped plateau of Graham Land. Eosinophils were counted on all lie-up days at the same time, 48 being completed on each man. The trek was characterized by periods of considerable danger-from hurricanes, treacherous sea-ice, and open crevasses-interspersed by periods of inactivity while we waited for the surface to improve. We were completely cut off, since there was no radio contact. Considering the long period away from base, little ground was covered (only 200 miles ; $315 \mathrm{~km}$.), and the results could not therefore be regarded as representative of dog-sledging in general.

With the collection of data it became apparent that three of the party showed only transient eosinopenias; in fact their combined results for the field period were negligibly different from the base-hut controls $(-4 \%)$. In contrast the leader (Subject C) went into a marked eosinopenia as soon as he left the base hut (see Chart), and this was sustained throughout the journey. At the end of the journey there was an immediate recovery to the initial control levels (see Chart). In fact, when all of his data were analysed from the point of view of environ-

\begin{tabular}{|c|c|c|c|}
\hline Situations* & Environment & $\begin{array}{l}\text { Eosinophil Count } \\
\text { per cu. mm. }\end{array}$ & $\mathrm{n}=$ \\
\hline $\begin{array}{l}1 \\
2 \\
3 \\
4\end{array}$ & 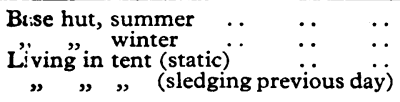 & $\begin{array}{r}129 \\
116 \\
80 \\
54\end{array}$ & $\begin{array}{l}10 \\
14 \\
21 \\
10\end{array}$ \\
\hline
\end{tabular}

* Subject C: situations 1 and 2 are not significantly different; situation 3 is significantly less than $2(P<0.01)$; and situation 4 is significantly less than 3 $(P<0.001)$

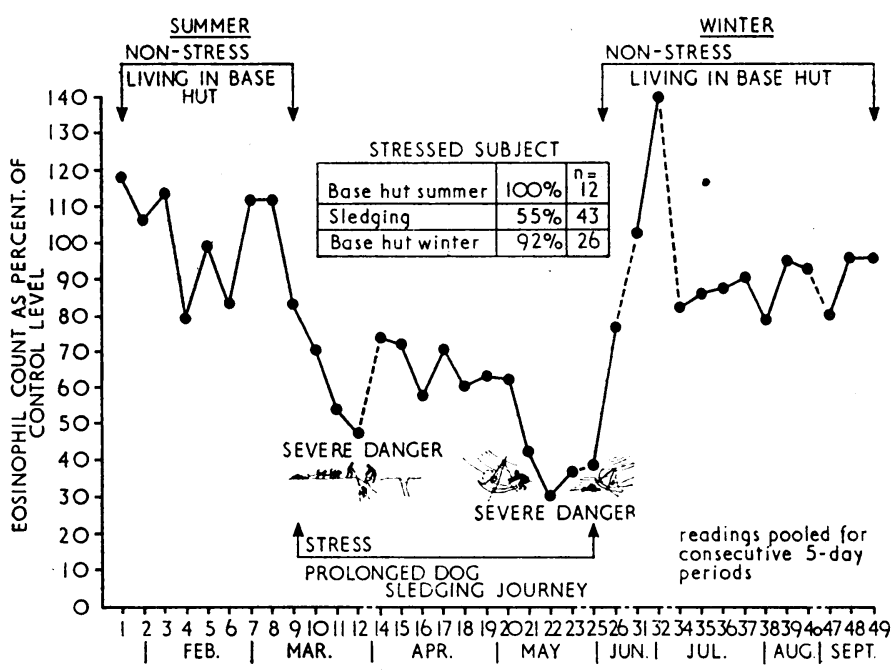

Subject $C$. Venous eosinophil counts made during a period of over nine months while he was leader of a British Antarctic base. To preserve simplicity, eosinophil counts for consecutive five-day periods have been pooled. During the first " severe danger" period there were several crevasse incidents when dogs had to be rescued; also there were two occasions when his dogs charged downhill out of control in heavily crevassed areas, since they could obtain no grip on the bare ice and became discouraged. In the second "severe danger" period both tents were blown down simultaneously in the middle of the night by gusts of were blown down simultaneously in the middle of the night by gusts of
wind estimated by the meteorologist at 80 knots $(148 \mathrm{~km}$.). Most of the supplies in $50-\mathrm{lb}$. (22.7-kg.) boxes were blown away. Note the prolonged eosinopenia during the sledging period and return to control levels afterwards; also, since these are morning counts, they reflect the previous day's events or anticipation of the current day. ments, different levels emerged for each (Table II). Isolated results from other journeys indicated that on these, too, he had a continuous eosinopenia, and it can therefore be inferred that he was in "stress" state for over six months of that year. Clinically this reaction correlated well with the fact that he was overweight, and for his second winter of antarctic tour he resigned the leadership, preferring the post of surveyor without responsibility for the base.

\section{A 237-mile (380-km.) Manhaul-sledge Journey}

As a contrast to section 1 , a journey was made with the specific intention of eliciting the effect of prolonged physical exertion on the eosinophil count. During this trek three men manhauled a 300-to-400-lb. (136-to-181-kg.) sledge 237 miles (380 $\mathrm{km}$.) around James Ross Island on the sea-ice. This is the classical British method of polar travel. Alternate mornings were left free to determine the eosinophil level in the venous blood. It worked out that on the day before the count an average distance of $18(15$ to 22$)$ miles $(29 ; 24$ to $35 \mathrm{~km}$.) had been sledged. By good fortune progress was never interrupted by bad weather. The results from this experiment are summarized in Table III. They show clearly that there was a morning (pre-exercise) eosinopenia for the duration of the journey (18 days).

TABLE III-Long-term Stress: a 237-mile (380-km.) Manhaul-sledge TABLE III-Long-term Stress a a fourney* $^{237-m i l e ~(380-k m .) ~ M a n h a u l-s l e d g e ~}$

\begin{tabular}{c|c|c|c}
\hline \multirow{2}{*}{ Subject } & \multicolumn{2}{|c|}{ Mean Eosinophil Level per cu. mm. } & Significance \\
& Control $(\mathrm{n}=17)$ & Stress $(\mathrm{n}=8)$ & Test) \\
\hline A & 237 & 110 & $\begin{array}{c}\mathrm{P}<0.001 \\
\mathrm{P}<0.01\end{array}$ \\
\hline 51 & 28 &
\end{tabular}

* Cnntrol and stress readings were taken at the same time of day to avoid diurna variation errors; the contrul data were obtained in the base hut.

\section{Stress of Skiing Across the Greenland Ice-cap}

Bearing in mind the results of section 2, I thought it would be of interest to study the adrenal response of a longer, more ambitious ski-manhauling journey with a more direct index of adrenocortical function-the 24-hour output of total 17-OHCS. The intention was to see if the continuous stress response of the journey in section 2 could be reproduced or, instead, to see if there was adaptation-that is, a high initial response falling to control levels even though the stress was sustained.

The geographical objective was to ski across Greenland from Angmagssalik on the east coast to Søndre Strømfjord on the west-400 miles $(640 \mathrm{~km}$.) of ice and a traverse of its type second only to Nansen's. A full description has been published (Simpson, 1965c). The results obtained are given in Table IV. Normal hormone levels were established while the party waited at Angmagssalik, as, with preparations for the crossing complete, we rested here for a week in comparative comfort. In three of the subjects confirmation of the authentic nature of these control values was available, since they were closely comparable to previous readings obtained during a Scandinavian holiday (see " holiday levels," Table IV).

During the first five days of the ice-cap journey, when we sledged over hazardous thawing sea-ice then up a steep crevassed glacier, there was a dramatic rise of output in the 17-OHCS (pooled mean $161 \%$ ), and these high levels were sustained over the next five days, when we were still climbing towards the 8,150 -ft. (2,484-m.) ice-cap summit (pooled mean $167 \%$ ). During the subsequent 15 days the party travelled fast over easy, almost level surfaces, and the five-day means fell successively $(158,141$, and $133 \%)$. Stress during this stage was largely physical-250 miles $(400 \mathrm{~km}$.) were skied in 12 days. 
Then followed the three five-day periods during which we descended to lower levels of the ice-cap and the hormone levels rose again to 154,151 , and $148 \%$. These increases corresponded closely to the increased stress experienced in traversing the thaw zone where rivers, slush, morasses, crevasses, and finally giant ice hummocks made progress desperately slow and accurate navigation impossible. After we had reached the security of the United States base at Søndre Strømfjord lower but still above-normal levels were observed over the week of measurement, the pooled mean value being $128 \%$. It should be noted, however, that the three men had a pooled mean of only $114 \%$, the $128 \%$ being heavily weighted by the woman's results.

The woman's readings were relatively very high during the crossing, and afterwards, a finding which correlates with the clinical observation that she was more physically exhausted by the trek and by the final effort of reaching safety than the men. In fact she commented that she did not feel "normal" for at least a fortnight after reaching security. Subject H's highest readings were recorded after he had made a navigational error which forced a detour. Physically he was the strongest member of the party and his relatively small rise for the middle part of the journey is in agreement with this. Subjects F and $\mathrm{E}$, the joint leaders, recorded their highest levels during the first five-day period, when they were faced with making a critical decision, which could have proved disastrous, concerning the glacier route to be taken to the ice-cap.

The results indicate that no adaptation took place, since throughout the journey the changes in steroid excretion paralleled the changing degrees of stress encountered.

On attempting to obtain a second set of control readings in the U.K. unexpectedly high levels were obtained-in some instances as high as those obtained on the ice-cap. This observation is discussed below.

\section{Discussion}

There is some criticism about the use of eosinophils as a measure of adrenocortical function, since adrenaline, from the medulla, is also capable of causing some eosinopenia. This question has been reviewed (Simpson, 1959), and the conclusion reached that should no fall be recorded in a supposed stress then both adrenocoritcal and medullary stimulation are unlikely; on the other hand, if a fall is recorded-especially if profound and sustained-then it is more likely to be due to cortical hormones, though some direct effect, and also potentiation, is likely from adrenaline. Noradrenaline has no effect on eosinophils (Humphreys and Raab, 1950). Of course adrenaline itself does not stimulate the adrenal cortex in man (Hunter, Bayliss and Steinbeck, 1955), though it does in some mammals (Vogt, 1944). Thus eosinophils are still a useful index of stress, especially where corticoid analysis is imprac- ticable. Moreover, an eosinopenia does appear to reflect the actual biological activity of corticoids, and so, as an index of adrenocortical function, it avoids the sweeping assumptions necessary with body fluid corticoid analyses-that is, constant protein-binding, hepatic inactivation, and renal excretion.

While the party were living in the Antarctic base hut the circulating eosinophil count was fairly stable. Significant depression from this level, however, occurred when exciting radio signals were " received"; in this isolated community all messages certainly had an exaggerated effect-nearly everyone exhibited mild manic behaviour and little work was done. Most men hated the summer shipping season because of the frequent signals and disruption of base routine; mail seemed small compensation. The majority were in fact attuned to the isolated Antarctic environment and preferred to have as little contact with the outside as possible. There has never been contact by plane with British bases and it is impracticable for ships to come in the winter.

Counts made the evening after a day's dog-sledging showed an invariable and profound eosinopenia as compared with control counts (mean $31 \%$ ). These were the lowest readings of the whole study. When counts were made the morning after a day's dog-sledging and night's sleep, but with the party still in the field, the results depended on the individual and the type of sledging. With most men there was only an eosinopenia if the journey was especially hazardous. However, in one individual, the mere fact of leaving the base hut resulted in a progressive profound eosinopenia for the full duration of the field period. Clinical confirmation of his stress state came when he resigned leadership.

A contrast is observed with the manhauling results in that a continuous stress response was invariably found, both when eosinophils and when urinary corticoids were used as an index. This is of possible interest in any discussion of why Amundsen was so much more successful than Scott in the South Pole journey. The eosinophil counts were all made in the morning after a night's rest and therefore probably represent a chronic effect-possibly adrenal hyperplasia. It is interesting that Subject E on the $237-\mathrm{mile}(380-\mathrm{km}$.) Antarctic journey was also on the 400-mile (640-km.) Greenland journey ; during the Antarctic journey he had an average eosinopenia of $52 \%(\mathrm{P}<0.01)$, whereas on the Arctic journey his 17-OHCS outputs averaged $+143 \%$ of control-that is, $21.5 \mathrm{mg}$./day compared with $15.0 \mathrm{mg}$. in the control period. This difference is again statistically significant.

The results of both journeys indicate that adaptation does not occur to the prolonged physical and mental stress of manhaul sledging ; it is reasonable to infer, therefore, that whatever physiological action the corticoids have in these situations it must be sustained throughout the stress. During the Greenland journey this was for more than a month.

Table IV.-Daily Outputs of 17-Hydroxycorticosteroids Before, During, and After the 400-mile (640-km.) Ski Crossing of Greenland

\begin{tabular}{|c|c|c|c|c|c|c|c|c|c|c|c|c|c|c|c|c|c|}
\hline & & & \multirow{2}{*}{\multicolumn{3}{|c|}{$\frac{\text { Subject G \& }}{17-\text { OHCS (mg.) }}$}} & \multirow{2}{*}{\multicolumn{3}{|c|}{$\frac{\text { Subject } \mathrm{H}_{\delta}}{17-\mathrm{OHCS} \text { (mg.) }}$}} & \multirow{2}{*}{\multicolumn{3}{|c|}{$\frac{\text { Subject } F \text { \& }}{17-\text { OHCS }(\mathrm{mg} .)}$}} & \multirow{2}{*}{\multicolumn{3}{|c|}{$\frac{\text { Subject E } \delta}{17-\text { OHCS }(\mathrm{mg} .)}$}} & \multirow{3}{*}{$\begin{array}{l}\text { Pooled } \\
\text { Mean } \\
(\%)\end{array}$} & \multirow{2}{*}{\multicolumn{2}{|c|}{ Stress Assessmen: }} \\
\hline & & & & & & & & & & & & & & & & & \\
\hline & & & Day \pm S.D. & $n=$ & $\%$ & Day \pm S.D. & $n=$ & $\%$ & Day \pm S.D. & $n=$ & $\%$ & Day \pm S.D. & $\mathrm{n}=$ & $\%$ & & Mental & Physical \\
\hline $\begin{array}{l}\text { Holiday levels } \\
\text { Pre-journey levels }\end{array}$ & . & & $\begin{array}{l}9 \cdot 6 \pm 1 \cdot 8 \\
9 \cdot 2 \pm 0.7\end{array}$ & $\begin{array}{l}9 \\
7\end{array}$ & $\begin{array}{l}104 \\
100\end{array}$ & $17 \cdot 2 \pm 1.8 \mid$ & To data & 100 & $\left|\begin{array}{|}10.9 \pm 1 \cdot 7 \\
10.7 \pm 2.9\end{array}\right|$ & $\begin{array}{l}8 \\
6\end{array}$ & $\begin{array}{l}102 \\
100\end{array}$ & $\begin{array}{l}16 \cdot 4 \pm 0.9 \\
15 \cdot 0 \pm 2 \cdot 3\end{array}$ & 4 & $\begin{array}{l}109 \\
100\end{array}$ & $\begin{array}{l}105 \\
100\end{array}$ & $\stackrel{ \pm}{ \pm}$ & $\begin{array}{l} \pm \\
\pm\end{array}$ \\
\hline \multicolumn{18}{|c|}{ Outputs Durring Crossing } \\
\hline 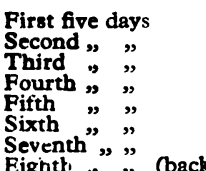 & $\begin{array}{l}\because \\
\because \\
\because \\
\because \\
\because\end{array}$ & $\begin{array}{c}\ddot{.} \\
\because: \\
\because \\
\ddot{n g}\end{array}$ & \begin{tabular}{|l|}
$16.6 \pm 3.8$ \\
$22.9 \pm 5.2$ \\
$21.0 \pm 2.1$ \\
$16.4 \pm 1.8$ \\
$14.2 \pm 0.9$ \\
$16.6 \pm 3.1$ \\
$16.7 \pm 2.6$
\end{tabular} & $\begin{array}{l}5 \\
5 \\
5 \\
5 \\
5 \\
5 \\
4\end{array}$ & $\begin{array}{l}180 \\
249 \\
228 \\
178 \\
154 \\
180 \\
182\end{array}$ & $\begin{array}{l}22 \cdot 2 \pm 3 \cdot 6 \\
21.5 \pm 2 \cdot 0 \\
19 \cdot 8 \pm 2 \cdot 3 \\
18.5 \pm 1 \cdot 1 \\
17 \cdot 7 \pm 1 \cdot 6 \\
22 \cdot 3 \pm 2.9 \\
28 \cdot 4 \pm 7 \cdot 9\end{array}$ & $\begin{array}{l}5 \\
5 \\
5 \\
5 \\
5 \\
4 \\
5\end{array}$ & $\begin{array}{l}129 \\
125 \\
115 \\
108 \\
103 \\
130 \\
165\end{array}$ & $\left|\begin{array}{|l|}18.4 \pm 3.6 \\
15.1 \pm 1.6 \\
15.7 \pm 1.8 \\
14.8 \pm 1.8 \\
14.4 \pm 1.4 \\
16.2 \pm 3.2 \\
14.6 \pm 1.6\end{array}\right|$ & $\begin{array}{l}\mathbf{5} \\
\mathbf{5} \\
\mathbf{5} \\
\mathbf{5} \\
\mathbf{5} \\
\mathbf{5} \\
5\end{array}$ & $\begin{array}{l}172 \\
141 \\
147 \\
138 \\
135 \\
151 \\
136\end{array}$ & $\begin{array}{l}24 \cdot 2 \pm 3 \cdot 1 \\
23 \cdot 2 \pm 1 \cdot 5 \\
21 \cdot 1 \pm 2 \cdot 6 \\
21 \cdot 0 \pm 2 \cdot 5 \\
21 \cdot 1 \pm 2 \cdot 3 \\
23 \cdot 3 \pm 4 \cdot 1 \\
18 \cdot 2 \pm 1 \cdot 6\end{array}$ & $\begin{array}{l}\mathbf{5} \\
5 \\
5 \\
5 \\
5 \\
5 \\
5\end{array}$ & $\begin{array}{l}161 \\
155 \\
141 \\
140 \\
141 \\
155 \\
121\end{array}$ & $\begin{array}{l}161 \\
167 \\
158 \\
141 \\
133 \\
154 \\
151\end{array}$ & $\mid \begin{array}{c}t+t+ \\
++t \\
++ \\
++ \\
+ \\
+++ \\
+++\end{array}$ & 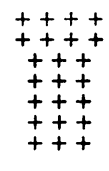 \\
\hline $\begin{array}{l}\text { Eighth, tü (bact } \\
\text { over tundra) } \\
\text { Immediate post-stre }\end{array}$ & $\begin{array}{l}\text { packin } \\
\text { ess perio }\end{array}$ & & $\begin{array}{l}19 \cdot 5 \pm 2 \cdot 7 \\
15 \cdot 9 \pm 2 \cdot 4\end{array}$ & $\begin{array}{l}5 \\
7\end{array}$ & $\begin{array}{l}212 \\
173\end{array}$ & $\begin{array}{l}24 \cdot 0 \pm 1 \cdot 8 \\
20 \cdot 1 \pm 4 \cdot 0\end{array}$ & $\begin{array}{l}5 \\
7\end{array}$ & $\begin{array}{l}140 \\
117\end{array}$ & $\begin{array}{l}11 \cdot 5 \pm 1 \cdot 3 \\
12 \cdot 7 \pm 2 \cdot 1\end{array} \mid$ & $\begin{array}{l}5 \\
5\end{array}$ & $\begin{array}{l}107 \\
119\end{array}$ & $\begin{array}{l}14 \cdot 8 \pm 1 \cdot 8 \\
15 \cdot 7 \pm 2 \cdot 5\end{array}$ & $\begin{array}{l}5 \\
5\end{array}$ & $\begin{array}{l}132 \\
105\end{array}$ & $\begin{array}{l}148 \\
128\end{array}$ & $\stackrel{ \pm}{ \pm}$ & $\underset{ \pm}{++}$ \\
\hline \multicolumn{18}{|c|}{ Outputs After Return } \\
\hline Normal routine in & U.K. . & .. & $|14 \cdot 0 \pm 2 \cdot 2|$ & 12 & 152 & $21 \cdot 4 \pm 2.9$ & 12 & 124 & $|19.0 \pm 3.8|$ & 12 & 178 & $24 \cdot 1 \pm 4 \cdot 2$ & $12 \mid$ & 161 & 154 & & \\
\hline
\end{tabular}


After the Greenland expedition an attempt was made to obtain a second set of control readings in the U.K., but unexpectedly high levels were obtained-in some instances as high as those from the ice-cap. Twelve observations were made on random days while the subjects were at their normal occupations; $\mathrm{G}$ is an author and housewife, $\mathrm{H}$ a company secretary, F a clinical lecturer, and $\mathrm{E}$ a school-teacher. Thus all the subjects held responsible and to a certain extent competitive jobs, and it is apparent that such occupations may result in more stress and adrenal cortical stimulation than has been hitherto recognized. It is of considerable interest that a university lecturer had a higher output of 17-OHCS during 12 random days of the busy autumn term period than at any time during a ski traverse of a 400 -miles $(640-\mathrm{km}$.) ice-cap, the average levels being $178 \%$ and $140 \%$ respectively above holiday controls. These observations accord with the fact that people in higher socio-economic groups tend to have higher steroid outputs-see discussions by Barnicot and Wolffson (1952), Politzer and Tucker (1958), and Edozien (1960). They also accord with my own observations that food-gathering Amerindians in the Surinam rain forest have much lower 17OHCS outputs than medical students in Glasgow, even when their smaller body mass is considered (Simpson, 1965a). However, it is probably too early to conclude that there is adrenal hyperfunction in affluent westerners; the results might merely indicate alteration in thyroid function and faster steroid turnover. More work has to be done, especially since the question is highly relevant in the aetiology of stress diseases.

It has often been presumed that stress is a threat of some sort to the organism and therefore something to be avoided. Is this so ? Some years ago Pugh (1954) showed that skiers at a resort were stressed in the evening, and he pointed out the obvious beneficial effects of these holidays. After a month of stress on our Greenland crossing we went straight on to complete a $250-$ mile $(400-\mathrm{km}$.) canoe journey up the coast, a journey in every way more dangerous than the sledging. Obviously the journey had not caused any marked deterioration in our physical condition. Equally, however, the leader of the long Antarctic sledging journey, who was stressed merely by camping in the field, was stressed sufficiently to resign the leadership. It would seem, therefore, that the difference between beneficial stress and that causing mental changes is a matter of degree and duration.

\section{Summary}

A field investigation of human stress situations in polar regions has been carried out. The blood eosinophil level and urinary 17-hydroxycorticosteroid output were used as indices of adrenal activity.

Men living in a British Antarctic sledging base had a fairly stable venous blood eosinophil count. Significant deviations from this level occurred when disturbing radio signals were received or when departure on a sledge journey was imminent. While in the field there was a profound eosinopenia in the evening after travelling and usually an extension of this to the following morning; in one instance the chronic eosinopenia lasted 85 days. Similarly in a party skiing 400 miles $(640 \mathrm{~km}$.) across the Greenland ice-cap there was a raised output of 17-OHCS in the urine for the full 40 days of the crossing from coast to coast. No adaptation to the stress took place.

The question of whether people in the higher socio-economic group have high $17-\mathrm{OHCS}$ excretion rates is discussed.

\section{BIBLIOGRAPHY}

Appleby, J. I., Gibson, G., Norymberski, J. K., and Stubbs, R. D. (1955).

Biochem. F., 60, 453.

Berkson, J., Magath, T. B., and Hurn, M. (1940). Amer. F. Physioi. 128. 309 .

Bliss, E. L., Sandberg, A. A., Nelson, D. H., and Eik-Nes, K. (1953). F. clin. Invest., 32, 818.

Doe, R. P., Flink, E. B., and Flint, M. G. (1954). 7. clin. Endocr., 14,

Edozien, J. C. (1960). Lancet, 1, 258.

Frost, J. W., Dryer, R. L., and Kohistaedt, K. G. (1951). 9. Lab. clin Med., 38, 523 .

Gabrilove, J. L. (1950). J. clin. Endocr., 10, 637.

Humphreys, R. J., and Raab, W. (1950). Proc. Soc. exp. Biol. (N.Y.) 74,302 .

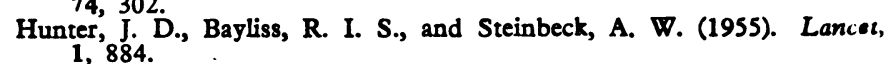

Kinloch, J. D. (1959). Brit. J. Nutr., 13, 85.

Peterson, R. E. (1957). ¥. clin. Endocr., 17, 1150.

Politzer, W. M., and Tucker, B. (1958). Lancet, 2, 778

Pugh, L. G. C. E. (1954). Proc. Nutr. Soc., 13, 60.

Pugh, L. G. C. E. (1954). Proc. Nu.

Simpson, H. Writ. (1959). M.̈. 1, Thesis, Edinburgh Undveralty.

(1965a). F. Endocr., 32, 179.

(1965b). Ph.D. Thesis, Glasgow University.

- (1965c). Med. Wld News, 6, No. 45, p. 44

Thorn, G. W (1953). Trans. Ass. Amer. Phycns, 66, 48

Forsham. P. H., Prunty, F. T. G., and Hills, A. G. (1948). 9. Amer. Med. Ass. 137., 1005.

Vogt, M. (1944). F. Physiol. (Lond.), 103, 317.

\title{
Behaviour Disorders and Pattern of Crime among XYY Males Identified at a Maximum Security Hospital
}

\author{
W. H. PRICE,* M.B., B.SC., M.R.C.P.ED. ; P. B. WHATMORE, $†$ M.B., LL.B., D.P.M.
}

Brit. med. F., 1967, 1, 533-536

In 1965 Jacobs et al. published the preliminary results of a chromosome survey of men who were patients at the State Hospital, Carstairs, and the final report on this is at present being prepared. The survey was undertaken to test the idea that men with an XYY sex chromosome complement might be unusually frequent among those in the special hospitals in England and in the State Hospital in Scotland. This idea stemmed from the finding by Casey et al. (1966b) of a relatively high frequency of males with an XXYY complement in Moss Side and Rampton and their known low frequency in hospitals for the mentally subnormal (Maclean et al., 1962) and among the newborn (Maclean et al., 1964).

Altogether nine XYY males were found, a frequency of nearly $3 \%$, and these findings have been substantiated by recent work at Moss Side, Rampton, and Broadmoor by Casey et al. (1966a). In a previous publication Price et al. (1966) reported the lack of evidence for abnormal physical development from examination of the nine XYY males at Carstairs. This paper reports the results of a detailed assessment of the behaviour characteristics of these men.

\section{The Hospital}

The State Hospital, Carstairs, is an institution provided by the Secretary of State for Scotland in terms of Part VII of the

\footnotetext{
- M.R.C. Clinical Effects of Radiation Research Unit, Western General Hospital, Edinburgh 4.

† State Hospital, Carstairs, Lanarkshire.
} 